\title{
Ammatillisen kehityksen merkitys opettajien jaksamisessa
}

\author{
HETA TUOMINEN-SOINI \& PASI SAHLBERG
}

\begin{abstract}
Onko täydennyskoulutuksen avulla mahdollista edistää opettajien työssä jaksamista? Jatkuva muutos koettelee opettajien voimavaroja. Kuitenkaan koulun arjen ja kehittämisvaatimusten välinen kuilu ei saisi kasvaa liian suureksi. Artikkelissa kuvattu tutkimus selvittää opettajien käsityksiä ja kokemuksia täydennyskoulutuksen merkityksestä jaksamiseen. Tutkimus on Uudistumisen eväät -tykyhankkeen itsenäinen jatkotutkimus.
\end{abstract}

pettajan ammattiin liittyy universaali dilemma. Opettajan yhtenä tehtävänä on säilyttää kulttuuriperinteitä ja vahvistaa olemassa olevaa järjestystä. Koulun tehtävänä on useimmissa koulutusjärjestelmissä kansakunnan kulttuuripääoman ja yhteiskunnassa omaksuttujen arvojen siirtäminen tuleville sukupolville. Toisaalta opettajan työhön ja koulutukseen kohdistetaan myös kasvavassa määrin odotuksia toimimisesta yhteiskunnallisena uudistajana ja muutoksen edistäjänä. Innovatiivisuus ja kehittäminen liitetään usein jälkimmäisiin tehtäviin, kun taas perinteinen opettaminen ja uudistusten välttäminen edellisiin. Opetuksen tehtävä monimuotoisessa epävarmuuden ja turvattomuuden maailmassa on lisännyt odotuksia opettajien kyvyille kasvattaa oppilaita aktiivisiksi tietoyhteiskunnan kansalaisiksi ja tietotalouksien edistäjiksi (Day 2000; Hargreaves 2003; Luukkainen 2004; OECD 2005).

Opettajan työn ja ammatti-identiteetin tarkasteleminen laaja-alaisemmin sai vauhtia 1990-luvun alussa, jolloin koulutuksen poliittinen ja taloudellinen konteksti olivat Suomessa muuttumassa. Tuolloin alettiin yleisesti puhua opettajuudesta, joka suhteellisen abstraktina käsitteenä on ymmärretty opettajan ammatin professionaalisina ja eettisinä ulottuvuuksina suhteessa vallitsevaan toimintaympäristöön. Opettajuudessa painotettiin tuolloin ennen kaikkea muutoksen kohtaamisen valmiuksia, laajempaa yhteiskunnallista vastuuta, toimimista asiantuntijana verkostoissa sekä opettajan työn eettisiä lähtö- kohtia (Helakorpi, Juuti \& Niemi 1996; Sahlberg 1997; Simola 1998; Kohonen \& Kaikkonen 1998). Myöhemmin näihin opettajan ammatin uusiin vaatimuksiin on lisätty erityinen eettinen ulottuvuus, joka on seurannut muun muassa kulttuurisen monimuotoisuuden, toiminnan vaihtoehtojen ja koulun oman päätösvallan kasvusta (Niemi, Kivimäki, Kuuskoski, Lindqvist \& Pursiainen 2002). Nämä nopeassa tahdissa kumuloituneet uudistusvaatimukset johtivat opettajien peruskoulutuksen ja ammatillisen kehittymisen mahdollisuuksien ja edellytysten tarkastelemiseenuudessa valossa.

Opettajuuden laaja-alaistuminen voidaan ymmärtää reaktiona opettajan työn toimintaympäristössä tapahtuneisiin muutoksiin (Day 2000; Opettajankoulutuksen kehittämisohjelma 2001; Luukkainen 2004). Nämä toimintaympäristön muutokset voidaan sijoittaa karkeasti kolmeen kategoriaan: yhteiskunnassa tapahtuvat kulttuuriset muutokset, koulutusjärjestelmässä tapahtuvat hallinnolliset ja rakenteelliset muutokset sekä opetuksessa ja oppimisessa tapahtuvat teoreettiset ja menetelmälliset muutokset. Tarkastellaan näitä kolmea muutoskategoriaa seuraavassa hieman lähemmin.

Yhteiskunnan kulttuuriset muutokset. Suomalainen yhteiskunta yleisesti ja koulumaailma erityisesti on kokenut kulttuurisen monimuotoistumisen viimeisen kymmenen vuoden aikana. Muutokset ovat näkyneet luokkahuoneissa oppilaiden etnisen kirjon laajenemisena. Eri kielet, us- 
konnot ja kulttuuriset tottumukset, joita oppilaat tuovat mukanaan luokkiin, vaativat opettajalta sekä uudenlaista tietämystä että aikaisempaajoustavampia asenteita erilaisuutta kohtaan (Talib 1999). Samaan aikaan perinteinen suomalainen yhteiskunta on muuttamassa muotoaan nuorison omaksumien 'alakulttuurien' ohjaamien toimintatapojen vaikutuksesta. Yhteiskunnan perusrakenteiden, kuten perheiden, lähiverkostojen ja sosiaalisen yhteenkuuluvuuden, muutokset heijastuvat selvästi opettajien arkitoimissa. Nämä ja muut yhteiskunnan rakenteissa ja kulttuurissa meneillään olevat muutokset näkyvät kouluissa opettajuuden laaja-alaistumisen vaatimuksina.

Koulujärjestelmän muutokset. Suomalainen koulujärjestelmä on kokenut perustavaa laatua olevan hallintorakenteen muutoksen 1990-luvun alusta lukien, mikä on vaikuttanut myös opettajien työhön ja ammatillisiin odotuksiin. Opetushallinnon päätösvallan siirtäminen kunnille ja kouluille on näkynyt opettajien työssä kahdella tavalla. Ensinnäkin opettajan rooli koulun toiminnan suunnittelijana ja päätöksentekijänä on muuttunut usein passiivisesta vastaanottajasta aktiiviseksi ja vastuulliseksi osalliseksi. Toiseksi paikallishallinnon vahvistaminen on tuonut mukanaan uudenlaisen tilivelvollisuuden, joka osaltaan heijastuu myös opettajien vastuun lisääntymisenä omien oppilaiden onnistumisesta koulussa. Samanaikaisesti hallinnon normien ja säädösten löysääminen on johtanut aikaisempaa tarkempaan oman koulun toiminnan seuraamiseen ja yhteistyöhön ympäröivän yhteisön, erityisesti vanhempien kanssa. Näiden muutosten yhteydessä on usein peräänkuulutettu opettajan uutta roolia, ei pelkästään kasvattajana ja opettajana, vaan myös oman työn ja työyhteisön kehittäjänä.

Opettamista ja oppimista koskevat muutokset. Oppimista ja opettamista koskevissa tieteissä tapahtuneet edistysaskeleet on usein tulkittu vaatimuksina muuttaa opettajien toimintaa kouluissa, erityisesti opetustilanteissa. 1990-luvulla 'uudet' tieto- ja oppimiskäsitykset haastoivat opettajat tarkastelemaan omaa toimintaansa, joskus kriittisestikin. Opetussuunnitelmien perusteissa edellytetään aikaisempaa selvemmin, että opetus kouluissa suunnitellaan konstruktivistisen opettamisen ja oppimisen hengessä. Opettajia vaaditaan integroimaan tieto- ja viestintätekniikka osaksi kokonaisvaltaista koulun toimintaa. Lisäksi opettajien olisi liitettävä kehittävä oppilasarviointi osaksi opiskeluprosessia. Nämämetatason pedagogiset muutokset näkyvät vaatimuksina aikaisempaa laaja-alaisempaanjajoustavampaan opettajuuteen sekä oman ammatin jatkuvaan kehittämiseen.

Opettajuuden uusien ulottuvuuksien on uskottu osaltaan vaikuttaneen opettajien kokeman työuupumuksen lisääntymiseen (Viinamäki 1997; Kulmala 2000; Wilhelm, Dewhurst-Savellis \& Parker 2000). Vaikka koulun sisäiset tekijät eivät yksin selitä opettajien kasvavaa ammatillista väsymystä, on opettajien kokemalla kouluympäristöllä tähän suuri

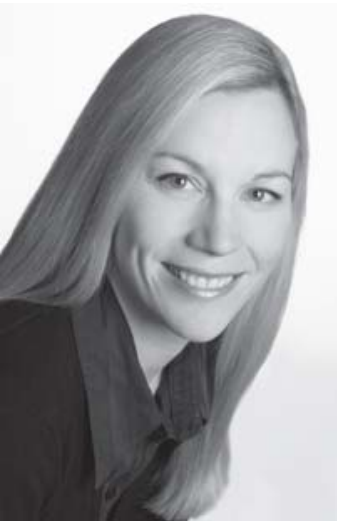

Heta Tuominen-Soini

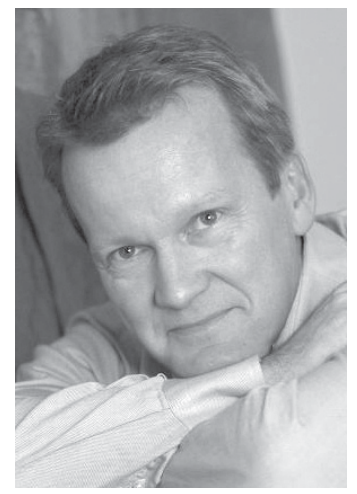

Pasi Sahlberg vaikutus. Lääkkeitä työuupumukseen on etsitty monelta taholta. Esimerkiksi tutkijoiden ja kansanedustajien yhteisessä julkilausumassa (Gabrielsson 2001) todetaan useaan otteeseen, että opettajuuden kriisiä tulisi hoitaa täydennyskoulutusta lisäämällä. Tämän artikkelin tarkoituksena onkin pohtia, onko täydennyskoulutuksen avulla mahdollista edistää opettajien työssä jaksamista.

\section{Täydennyskoulutus opettajan työssä}

Jatkuvan muutoksen keskellä opettajakaan ei ole koskaan valmis ammattilainen. Opettajan varsinainen ammatillinen kypsyminen tapahtuukin vasta työelämässä ja se on koko työuran kestävä oppimisprosessi. Jatkuva muutos koettelee kuitenkin opettajan voimavaroja. Opettajia pitäisi valmistaa muutoksen kohtaamiseen, jotta he oppisivat näkemään sen mahdollisuutena ja oman työn kannalta hyvänä asiana. Syrjäläisen (2002) mukaan uudistusten tulisi olla opettajalle mielekkäitä ja merkityksellisen tuntuisia, jotta opettaja voisi innostua niistä, kehittyä ammatillisesti 
niiden myötä sekä saada voimavaroja. Opettajan oman käytännön työn kannalta merkityksettömät, työläät projektit aiheuttavat turhautumista ja loppuunpalamista. Koulun arjen ja uudistusvaatimusten välinen kuilu ei saisi kasvaa liian suureksi.

Erityisesti työhön ja sen tavoitteisiin vahvasti sitoutuvat, tunnolliset ja ahkerat opettajat ovat vaarassa uupua (ks. Fullan 1993; Vartiovaara 1996; Kalimo \& Toppinen 1997; Hargreaves 2003). Easthopen ja Easthopen (2000) australialaisten opettajien työtaakan kasvua selvittäneen pitkittäistutkimuksen mukaan opettajien työpäivät olivat pidentyneet, opetusryhmät suurentuneet ja työtehtävät paitsi lisääntyneet myös monipuolistuneet kymmenen vuoden aikana. Tämä johti siihen, että opettajat eivät selviytyneet kaikista työtehtävistään. He kokivat erittäin stressaavana ja syyllisyyden tunteita herättävänä sen, että he eivät jaksaneet eivätkä ehtineet tehdä työtään yhtä hyvin kuin aiemmin. Tästä seurasi, että jotkut opettajat jättivät opettajan työn kokonaan, kun taas toiset vähensivät stressiä ryhtymällä osaaikaisiksi opettajiksi. Opettajan ammattiin jääneet joutuivat joko vähentämään sitoutumistaan työhönsä tai jatkamaan vanhaan malliin, mutta kärsien voimakkaista stressioireista. (Easthope \& Easthope 2000.)

Täydennyskoulutus on samanaikaisesti opettajan velvollisuus ja oikeus. Sen tavoitteena on ensisijaisesti opettajan ammatillisen osaamisen kehittäminen, mutta täydennyskoulutus liitetään nykyisin myös koko kouluyhteisön toiminnan edistämiseen ja meneillään olevien uudistusten toimeenpanon vauhdittamiseen. Täydennyskoulutusta pitkään leimannut voimakas lyhytkurssiperinne on aiheuttanut sen, että oppilaitoksen kehittämistyön vaatima prosessinomaisuus jää usein huomiotta ja täydennyskoulutus suuntautuu yksilöllisen ammatillisen kehittymisen tukemiseen, jolloin se ei suosi ryhmiä tai koko oppilaitosyhteisöä huomioonottavaa lähestymistapaa (Kosunen \& Mikkola 2001). Selvitysten mukaan täydennyskoulutuksessa on Suomessa kuitenkin siirrytty yksittäisistä lyhytkursseista yhä enemmän kohti pidempikestoisia ja koulukohtaisia kehittämisohjelmia (Luukkainen 2000).

Osallistuminen useamman opintoviikon laajuiseen koulutukseen edellyttää opettajalta sitoutumista sekä aikaa erilaisille välitehtäville ja usein myös verkossa tapahtuvalle opiskelulle. Täydennyskoulutuksen järjestäjät ovat tilivelvollisia koulutuksen rahoittajille siitä, että opettajat tekevät sovitun määrän työtä koulutuksen aikana. Koulutuskustannuksista tinkiminen on johtanut siihen, että entistä suurempi osa täydennyskoulutuksesta toteutetaan tavalla tai toisella itseohjautuvana tai etäopiskeluna perinteisen koulutuksen yhteydessä. Onkin syytä kysyä, millainen vaikutus tällä lisääntyneellä itsenäisellä opiskelulla on opettajien väsymiseen ja kiireeseen. Opettajien asenteet ja mahdollisuudet osallistua ammatilliseen täydennyskoulutukseen vaihtelevat sen mukaan, millaisesta koulutuksesta on kulloinkin kysymys.

Ammatillisen kehityksensä tueksi opettaja tarvitsee pitkäjänteisesti suunniteltua, tarkoituksenmukaisesti toteutettua sekä henkilökohtaisiin tarpeisiin ja toisaalta koulun ja yhteiskunnan tarpeisiin perustuvaa täydennyskoulutusta (Meriläinen 1997). Kysymys ammatillisen kehityksen, sekä erityisesti täydennyskoulutuksen, yhteydestä työuupumukseen on mielenkiintoinen, mutta ei yksinkertainen. Tässä tarkastelussa tulee erottaa opettajille virkaehtosopimuksen mukaan velvoitettu koulutus ja toisaalta opettajien omista tarpeista ja mahdollisuuksista lähtevä omaehtoinen kouluttautuminen. Kysymys voidaan asettaa myös näin: Millä edellytyksillä täydennyskoulutus ja muu ammatillinen kehittyminen edistää opettajan jaksamista ja henkistä hyvinvointia työssä?

\section{Tutkimus ja sen toteutus}

Tämän artikkelin taustana olevan tutkimuksen (ks. Tuominen 2002) tarkoituksena oli selvittää kyselytutkimuksen avulla opettajien työuupumuksen ja ammatillisen kehityksen välistä yhteyttä. Lisäksi ryhmähaastattelujen avulla pyrittiin selvittämään tarkemmin opettajien käsityksiä ja kokemuksia siitä, millainen merkitys täydennyskoulutuksella on työssä jaksamisessa. Näkökulma käännettiin uupumisesta jaksamiseen. Tutkimus on Kuopion koulutoimessa vuosina 1999-2001 toteutetun Uudistumisen eväät tykyhankkeen itsenäinen jatkotutkimus. Kyselytutkimukseen osallistuivat tykyhankkeen kuuden pilottikoulun opettajat $(N=110)$ sekä kuuden hankkeeseen osallistumattoman Kuopion koulun opettajat $(N=142)$. Mukana oli kuusi ala-astetta, kolme yläastetta ja kolme lukiota. Kyselylomakkeita palautui 131 ja vastausprosentti oli 52. Muistutuskirjeitä ei lähetetty. Lisäksi tehtiin kol- 
me ryhmähaastattelua, joihin kuhunkin osallistui 3-4 opettajaa. Mukana oli yksi ala-aste, yläaste ja lukio. Tarkempi selostus tutkimuksen toteuttamisesta sekä käytetty kyselylomake kokonaisuudessaan löytyvät alkuperäisestä tutkimuksesta (ks. Tuominen 2002).

Aineistonhankintamenetelmänä kyselylomaketutkimuksessa käytettiin itse rakennettua Likert-tyyppistä kyselylomaketta. Työuupumusta arvioivien väittämien laatimisessa hyödynnettiin mallia, jossa työuupumus nähdään kolmitahoisena häiriönä. Tämän stressioireyhtymän kolme tyypillistä piirrettä ovat uupumusasteinen väsymys, kyynistyneisyys ja heikentynyt ammatillinen itsetunto (Maslach, Schaufeli \& Leiter 2001; Kalimo \& Toppinen 1997). Väittämiä olivat muun muassa: "Tunnen olevani lopen uupunut työstäni", "Työni tuntuu mielekkäältä" (käänteinen väittämä) ja "Pelkään, etten suoriudu työtehtävistäni".

Ammatillista kehitystä arvioivien väittämien operationaalistamisen lähtökohtana oli itse muodostettu hypoteettinen malli, joka koostui viidestä osa-alueesta: opettajan pedagogiset taidot, persoonallisuus, oppimisorientaatio, sosiaaliset taidot ja muutoksen kohtaaminen. Malli rakennettiin Niemen (1989) kokoaman hypoteettisen mallin pohjalta, jossa on kolme keskeistä aluetta: ammatilliset taidot, persoonallisuus ja kognitiiviset prosessit. Väittämiä olivat esimerkiksi: "Tunnen, että olen kehittänyt oman kasvattajaidentiteetin", "Selviydyn hyvin erilaisten oppilaiden ja ryhmien opetuksesta", "Valitsen mielelläni haastavia työtehtäviä, joista voin oppia paljon", "Keskustelen työhön liittyvistä asioista paljon muiden opettajien kanssa" ja "Haluan tehdä työtä, johon liittyy muutoksia ja vaihtelua".
Faktorianalyysin avulla pyrittiin tiivistämään alkuperäiset työuupumusta ja ammatillista kehitystä kuvaavat informaatiot muutamiin jatkoanalyyseihin soveltuviin muuttujiin. Faktorimenetelmänä oli pääkomponenttianalyysi ja rotaatiomenetelmänä varimax-rotaatio. Haastattelut olivat tyypiltään puolistrukturoituja teemahaastatteluja ja analyysitapana käytettiin teemoittelua.

\section{Työuupumus ja ammatillinen kehitys}

Pääkomponenttianalyysin perusteella opettajien työuupumukseen liittyivät uupumusasteinen väsymys, kyynistyneisyys ja heikentynyt ammatillinen itsetunto. Ensimmäinen pääkomponentti oli yleinen jatkuvan väsymyksen ja uupumuksen ulottuvuus. Tähän ulottuvuuteen liittyi myös opettajan pelko siitä, ettei hän suoriudu työtehtävistään. Toiselle pääkomponentille latautuivat voimakkaasti työn iloa ja työn mielekkyyttä mittaavat osiot. Nämä käänteiset osiot mittaavat kyynistyneisyyttä. Pääkomponentille latautui myös energisyyttä ja arvostusta kuvaavia väittämiä. Nämä voidaan tulkita käänteisinä merkkeinä kyynistyneisyyteen liittyvästä innostuksen laskusta ja työhön liittyvistä pettymyksistä. Kolmas työuupumuksen ulottuvuus oli heikentynyt ammatillinen itsetunto. Tälle pääkomponentille latautuivat pätevyyden ja työn hallinnan tunteet. Pääkomponentit pystyivät selittämään 58 prosenttia muuttujien varianssista.

Ammatillisen kehityksen analysoinnissa päädyttiin neljän pääkomponentin ratkaisuun. Alkuperäinen mittari perustui malliin, jossa oli viisi ulottuvuutta, mutta neljän pääkomponentin ratkaisu oli helpoiten tulkittavissa sisällöllisesti. Ammatilliseen kehitykseen liittyivät opettajan

TAULUKKO 1. Työuupumuksen ja ammatillisen kehityksen osa-alueiden korrelaatiokertoimet ja p-arvot

\begin{tabular}{|l|c|c|c|}
\hline Summamuuttujat & $\begin{array}{c}\text { Uupumus- } \\
\text { asteinen } \\
\text { väsymys }\end{array}$ & $\begin{array}{c}\text { Kyynisty- } \\
\text { neisyys }\end{array}$ & $\begin{array}{c}\text { Heikentynyt } \\
\text { ammatillinen } \\
\text { itsetunto }\end{array}$ \\
\hline Persoonallisuus ja pedagogiset taidot &,$- 437^{* \star}$ &,$- 475^{* \star}$ &,$- 562^{\star *}$ \\
\hline Oppimisorientaatio &, 000 &, 000 &, 000 \\
\hline Sosiaaliset taidot &,- 125 &,$- 351^{\star *}$ &,$- 453^{\star *}$ \\
\hline Muutoksen kohtaaminen &, 162 &, 000 &, 000 \\
\hline
\end{tabular}

**. Korrelaatio on tilastollisesti merkitsevä $(p<0.01)$. 
persoonallisuus ja pedagogiset taidot, oppimisorientaatio, sosiaaliset taidot sekä muutoksen kohtaaminen. Ensimmäisessä pääkomponentissa yhdistyivät persoonallisuus ja pedagogiset taidot; oman kasvattajaidentiteetin, kasvatusfilosofian ja persoonallisen tyylin löytäminen sekä oppilaiden ja itsen ymmärtäminen. Toisessa ulottuvuudessa korostuivat opettajan asennoituminen omaan oppimiseen, kriittinen ajattelu, avoimuus uusille ideoille ja joustavuus. Kolmas pääkomponentti kuvasi sosiaalisia taitoja. Viimeinen pääkomponentti liittyi muutoksen kohtaamiseen ja siihen suhtautumiseen. Pääkomponentit selittivät $48 \%$ muuttujien varianssista.

Summamuuttujien reliabiliteettia tarkasteltiin Cronbachin alfa-kertoimen avulla. Saadut kertoimet olivat .75 ja .92 välillä. Summamuuttujien välisiä yhteyksiä selvitettiin korrelaatiotarkasteluilla. Työuupumuksen ja ammatillisen kehityksen välillä oli korkea korrelaatio (-.53). Opettajan kehittyessä ammatillisesti hänen taipumuksensa kokea työuupumusta siis vähenee ja päinvastoin. Yhteys on tilastollisesti erittäin merkitsevä $(p=.000)$.

Tilastollisesti merkitseviä yhteyksiä löytyi myös näiden muuttujien osa-alueiden väliltä (ks. taulukko 1). Persoonallisuus ja pedagogiset taidot -summamuuttuja oli yhteydessä kaikkiin työuupumuksen oireisiin. Jos siis opettaja ei ole kehittänyt omaa kasvattajaidentiteettiään eikä ole löytänyt omaa persoonallista tapaansa opettaa ja olla vuorovaikutuksessa oppilaiden kanssa, hänen taipumuksensa uupua on suurempi kuin opettajan, joka on löytänyt oman tyylinsä toimia opettajana. Persoonallisuuteen ja pedagogisiin taitoihin oli voimakkaimmin yhteydessä heikentynyt ammatillinen itsetunto (-.56). Kohtalaisen korkeita olivat myös korrelaatiot uupumusasteiseen väsymykseen (-.44) ja kyynistyneisyyteen (-.48). Esimerkiksi uudistusten myötä ammatti-identiteettiään jatkuvasti muokkaamaan joutuva opettaja kokee siis uupuessaan todennäköisesti opettajana menestymisen kyseenalaistamista, työn mielekkyyden katoamista sekäjatkuvaa väsymystä.

Työuupumuksen oireisiin olivat yhteydessä myös muutoksen kohtaamisen taidot. Jos koulussa tapahtuvat muutokset aiheuttavat opettajassa runsaasti ahdistusta eikä hän halua tehdä työtä, johon liittyy muutoksia ja vaihtelua, hänen taipumuksensa kokea kyynistyneisyyttä (.43), uupumusasteista väsymystä (-.39) ja heiken- tynyttä ammatillista itsetuntoa (-.37) kasvaa. Jatkuvat uudistukset vaikuttavatkin varmasti kielteisesti juuri työn mielekkyyden kokemiseen, jos opettaja kokee muutokset uhkana eikä haasteena. Jatkuva muutos saattaa väsyttää tällaista opettajaa ja aiheuttaa ammatillisen itsetunnon heikkenemistä, jos opettaja ei tunne selviävänsä uusista haasteista. Muutoksen kohtaaminen -osaalueen yhteys uupumukseen voi kertoa myös siitä, että jos opettaja on jo uupunut, hän saattaa muuttaa asennettaan muutosta kohtaan aiempaa kielteisemmäksi, jos hän ei tunne selviytyvänsä vanhoista työtehtävistäänkään.

Heikentyneen ammatillisen itsetunnon ja oppimisorientaation välinen yhteys (-.45) oli kohtalaisen korkea. Jos siis opettajan omat oppimisen, kriittisen ajattelun ja ongelmanratkaisun taidot ovat ruosteessa, hän saattaa alkaa epäillä pätevyyttään ja kykyään hallita opettajan työtä. Jos opettaja ei suhtaudu omaan oppimiseensa myönteisesti, saattaa hän alkaa epäillä myös työnsä mielekkyyttä (-.40). Näitä yhteyksiä voidaan jälleen tarkastella myös päinvastoin eli heikentynyttä ammatillista itsetuntoa ja kyynistyneisyyttä kokevalla opettajalla on taipumus suhtautua kielteisesti omaan oppimiseensa ja kyseenalaistaa sen merkitystä. Väsymykseen opettajien oppimisorientaatio ei kuitenkaan ollut tilastollisesti merkitsevässäyhteydessä.

Opettajan sosiaaliset taidot olivat yhteydessä kyynistyneisyyteen (-.40) ja heikentyneeseen ammatilliseen itsetuntoon (-.33). Opettaja, joka ei ole halukas tai kykenevä yhteistyöhön muiden opettajien kanssa, tuntee siis todennäköisesti työn mielekkyyden katoamista ja oman pätevyyden kyseenalaistamista. Toisaalta, jos yhteyttä tarkastellaan toisin päin, voidaan todeta, että kyynistynyt ja heikentyneestä ammatillisesta itsetunnosta kärsivä opettaja alkaa mahdollisesti karttaa yhteistyötä muiden kanssa. Mutta onko niin, että sosiaalisilta taidoiltaan heikko opettaja ei kuitenkaan välttämättä väsy työssään? Tällainen opettaja saattaa siis yhtä hyvin tuntea kuin olla tuntemattakin uupumusasteista väsymystä.

Ammatillisen kehityksen osa-alueista 'persoonallisuus ja pedagogiset taidot' sekä 'muutoksen kohtaamisen taidot' olivat siis voimakkaimmin yhteydessä työuupumukseen sekä kaikkiin sen oireisiin. 'Oppimisorientaatio' ja 'sosiaaliset taidot' olivat yhteydessä kyynistyneisyyteen ja heikentyneeseen ammatilliseen itsetuntoon mutta eivät uupumusasteiseen väsymykseen. 
TAULUKKO 2. Työuupumuksen ja sen osa-alueiden keskiarvot, mediaanit, keskihajonnat sekä $25 \%$ ja $75 \%$ prosenttipisteet (vastausvaihtoehdot: $1=$ ei koskaan, $2=$ muutaman kerran vuodessa, $3=$ muutaman kerran kuukaudessa, 4 = kerran viikossa, 5 = muutaman kerran viikossa ja 6 = päivittäin)

\begin{tabular}{|llllll|}
\hline Summamuuttuja & Ka & Md & S & $\mathrm{Q}^{1}$ & $\mathrm{Q}^{3}$ \\
\hline TYÖUUPUMUS & 2,3 & 2,2 &, 75 & 1,8 & 2,8 \\
Uupumusasteinen väsymys & 2,6 & 2,4 &, 98 & 1,9 & 3,1 \\
Kyynistyneisyys & 2,1 & 2,0 &, 82 & 1,5 & 2,6 \\
Heikentynyt ammatillinen itsetunto & 1,8 & 1,7 &, 86 & 1,0 & 2,0 \\
\hline
\end{tabular}

Aineistoa voidaan kuvailla myös summamuuttujien keskiarvojen, mediaanien, keskihajontojen sekä ala-ja yläkvartiilien avulla (ks. taulukot 2 ja 3). Työuupumuksen keskiarvot eivät ole kovin korkeita. Kuitenkin jos tarkastelemme uupumusasteisen väsymyksen 75 prosenttipistettä, huomaamme, että noin neljännes opettajista tunsi kokevansa voimakkaita väsymyksen ja uupumuksen oireita muutaman kerran kuukaudessa tai useammin. Vastaajia pyydettiin myös arvioimaan omaa työssä jaksamistaan asteikolla yhdestä kuuteen ( 1 = jaksan erittäin hyvin, 6 = olen lopen uupunut). Suuri osa opettajista näytti jaksavan työssään melko hyvin; 80 prosenttia opettajista vastasi rastittamalla 1:n, 2:n tai 3:n. Vaikka vastausten keskiarvo on 2,6 ( $s=1,09)$, ei kuitenkaan tule ohittaa sitä seikkaa, että 20 prosenttia opettajista tunsi olevansa uupuneita työssään.

Opettajat näyttivät kokevan oman ammatillisen kehityksensä tason hyvin korkeana. He arvioivat erityisesti omat sosiaaliset taitonsa korkeiksi $(\mathrm{ka}=4,2$ ja $s=0,55)$. Muutoksen kohtaamisen taidot opettajat kokivat ammatillisen kehittymisen ulottuvuuksista heikoimmiksi $(\mathrm{ka}=3,7 \mathrm{ja} s=$ $0,74)$.

\section{Täydennyskoulutus ja työssä jaksaminen}

Tämän tutkimuksen mukaan täydennyskoulutuksen avulla voidaan edistää opettajien työssä jak- samista. Täydennyskoulutus on kuitenkin vain yksi työssä jaksamista edistävä tekijä muiden joukossa. Sitä pidettiin jaksamista edistävänä tekijänä erityisesti sen takia, että opettajan omista tarpeista lähtevä täydennyskoulutus voi tarjota runsaasti virikkeitä, lisätä motivaatiota sekä antaa tätä kautta eväitä myös työssä jaksamiseen. Yksi tärkeä työssä jaksamista edistävä seikka täydennyskouluttautumisessa on myös opettajan oman osaamisen paraneminen. Ammattitaidon päivittäminen onkin erityisen tärkeää tällaisena aikana, kun sisällöt ja opetusmenetelmät muuttuvat usein. Täydennyskoulutuksen avulla opettajat voivat palauttaa mieliin aiemmin opittuja asioita sekä oppia uutta. Koulutuksen avulla päivitetty ammattitaito tuo opettajille varmuutta, mikä puolestaan edistää jaksamista. Tärkeäksi koettiin myös mahdollisuus hengähtää ja päästä hetkeksi pois arjen opetustyöstä.

Työssä jaksamista edistäväksi tekijäksi mainittiin myös muiden opettajien ja alan ihmisten tapaaminen täydennyskoulutustilaisuuksissa. Juuri muiden opettajien kanssa keskusteleminen, kokemusten vaihto ja ratkaisujen pohtiminen yhteisiin ongelmiin koettiin voimia antavaksi. Opettajat korostivat opettajien välisen yhteistyön, hyvien inmissuhteiden ja ilmapiirin merkitystä jaksamisessa. Muutamat opettajat kuitenkin totesivat, että opettajan työ on suurelta osin yhä yksin työskentelyä luokassa ja että jotkut opettajat saattavat jaksaa työssään myös ilman

TAULUKKO 3. Ammatillisen kehityksen ja sen osa-alueiden keskiarvot, mediaanit, keskihajonnat sekä $25 \%$ ja $75 \%$ prosenttipisteet (asteikko: 1 = täysin eri mieltä, 5 = täysin samaa mieltä)

\begin{tabular}{|lccccc|}
\hline Summamuuttuja & Ka & Md & S & $\mathrm{Q}^{1}$ & $\mathrm{Q}^{3}$ \\
\hline AMMATILLINEN KEHITYS & 3,9 & 3,9 &, 43 & 3,7 & 4,3 \\
Persoonallisuus ja pedagogiset taidot & 3,9 & 3,9 &, 53 & 3,5 & 4,4 \\
Oppimisorientaatio & 3,9 & 3,9 &, 52 & 3,6 & 4,2 \\
Sosiaaliset taidot & 4,2 & 4,1 &, 55 & 3,9 & 4,6 \\
Muutoksen kohtaaminen & 3,7 & 3,8 &, 74 & 3,3 & 4,3 \\
\hline
\end{tabular}


tiivistä yhteistyötä muiden opettajien kanssa. Yhteistyötähän voi tehdä myös muiden kuin oman koulun opettajien kanssa tai muiden aikuisten kanssa, ei välttämättä vain opettajien. Eli niin kuin aiemmin totesimme, opettajan sosiaaliset taidot eivät ole yhteydessä uupumusasteiseen väsymykseen. Opettajan haluttomuus tehdä yhteistyötä muiden opettajien kanssa ei siis vielä kerro opettajan taipumuksesta väsyä, mutta taipumus kyynistymiseen ja ammatillisen itsetunnon heikkenemiseen silti kasvaa.

Täydennyskoulutuksen ja työssä jaksamisen välinen suhde ei ole kuitenkaan yksinkertainen. Vaikka täydennyskoulutus tarjoaisikin virkistystä, ammatillista kehitystä ja välimatkaa opetustyön arkeen, siihen osallistuminen vaatii opettajalta paljon aikaa, omaa aktiivisuutta ja voimia. Opettaja joutuu usein ottamaan itse selvää koulutuksista ja näkemään paljon vaivaa käytännön asioiden hoitamisessa. Tämä saattaa tuntua jo niin uuvuttavalta, että opettaja päättääkin säästää voimansa pakolliseen - opetustyöhön. Erityisen hankalaksi koulutukseen osallistuminen koetaan silloin, kun olosuhteet koulussa ovat jostain syystä huonot ja opettajat kokevat epävarmuutta tulevaisuudesta. Tällöin koulutus tulee kaiken muun huolen rinnalle, mikä uuvuttaa opettajaa entisestään. Täydennyskoulutuksen tulisikin ehtiä ennen uupumusta; uupunut opettaja ei jaksa nähdä koulutukseen osallistumisen vaatimaa vaivaa eikä toisaalta myöskään hyödy koulutuksesta yhtä paljon kuin hyvin jaksava opettaja. Myös koulutuksessa saatujen ideoiden toteuttaminen käytännössä saattaa jäädä uupuneelta opettajalta vähäiseksi. Yksi haastatelluista opettajista sanoi, että

"niin, ja sitten jotenkin tuntuu, että tän täydennyskoulutuksenkin pitäs jotenkin ennättää ennen kun sitä uupuu liikaa, koska sitten siinä vaiheessa, kun alkaa uupua, niin sitten ei jaksa enää lähteä. Tai vaikka meniskin, niin ei siitä enää oo sitten sitä hyötyä. Ja kuitenkin sitten sitä pitäis vielä kun on käyny siellä, niin sen jälkeen toteuttaa niitä ideoita koulussa. Se vaatis kuitenkin vähän semmosta virkistystä."

Koulutuksen vapaaehtoisuus ja oma-aloitteisuus koulutukseen hakeutumisessa saattaa olla toisille kynnyskysymys. Koulutuksen tarjonta ja tarpeellisen koulutuksen saatavuus ei aina välttämättä ole suurin ongelma. Monet opettajat ni- mittäin kokevat oman opetustyön tärkeimpänä. Opettamisen ensisijaisuutta painotettiin sanomalla, että

"varmasti paljon on koulutusta tarjolla, jos on itse aktiivinen ja päättäis, että osallistuu johonkin. Kuitenkin on semmonen tuntu, että se on tää koulutyö se joka pitää ensiksi hoitaa. Jos jää voimia niin sitten. Vaikka toisaalta siitä ois varmasti myös virkistystä, että osallistuis välillä koulutukseen, joka sitten auttais."

Monissa tutkimuksissa on todettu, että aika on opettajan työn pahin vihollinen (Hargreaves 1994; Sahlberg 1996; Stoll, Fink \& Earl 2003; Johnson 2006). Täydennyskoulutusta toteutetaan aikaisempaa useammin iltaisin ja viikonloppuisin, mikä saattaa rajoittaa koulutukseen osallistumista. Tämä kuuluu opettajan omin sanoin näin:

"Ja sitten myös sekin, että jaksaako lähteä mihinkään täydennyskoulutukseen, vaikka ois mahollistakin. Että sitten saattaa olla, että jättää senkin takia, että yksinkertasesti on ensimmäinen viikonloppu kun saa levätä."

Opettajat mainitsivat myös, että vaikka täydennyskoulutus tarjoaisikin virikkeitä ja uudistusta, eivät opettajat kuitenkaan jaksa, jos koulun muut rakenteet eivät ole jaksamista tukevia. Täydennyskoulutuksen avulla on vaikea edistää jaksamista, jos opetusryhmät ovat liian suuria, kiire on liian kova eivätkä opettajat saa arvostusta eivätkä tukea työssään.

Opettajat pitivät ammattitaidon ylläpitämistä ja ammatillista kehitystä tärkeänä osana ammattiaan. Myös pitkien koulutusten, esimerkiksi yliopistollisten arvosanojen, suorittaminen nähtiin erittäin motivoivana, vaikka tällainen opiskelu työn ohella onkin työlästä. Koulutus tarjoaa opettajalle kuitenkin mahdollisuuden irtautua niin työ- kuin kotiympyröistäkin, mikä jo sinällään saattaa olla virkistävää ja tervetullutta vaihtelua arkeen. Tulosten mukaan täydennyskoulutus, joka auttaa opettajaa jaksamaan työssään paremmin, voi olla niin lyhyt- kuin pitkäkestoistakin ja se voi käsitellä vaikkapa aineenhallintaa, opetusmenetelmiä tai työssä jaksamista ja stressinhallintaa. Tärkeintä on, että koulutus lähtee opettajan ja koulun tarpeista, on kiinnostavaa ja opettajan omaa osaamista edistävää. Opettajat kokivat tärkeäksi myös sen, että koulutus oli aiheeltaan ajankohtainen ja tutkimukseen pohjautuva. 
Useat toivoivatkin kuulevansa koulutuksessa viimeisintä tutkimustietoa alaltaan.

\section{Pohdinta}

Tutkimuksessa todettiin, että opettajien työuupumus ja ammatillinen kehitys ovat yhteydessä toisiinsa. Tutkimuksen heikkoutena on kuitenkin se, että tulokset perustuvat poikkileikkausaineistoon ja ovat siksi viitteellisiä. Syy-yhteyksiä tulisikin tarkastella pitkittäistutkimuksen avulla. Lisäksi kyselytutkimuksen vastausprosentti jäi melko alhaiseksi, koska muistutuskirjeitä ei lähetetty. Tulosten luotettavuutta parantaa kuitenkin se, että kysely- ja haastattelututkimuksen tulokset tukivat toisiaan. Tutkimuksessa todettiin myös, että opettajille suunnattu täydennyskoulutus on mahdollinen, muttei kuitenkaan automaattinen lääke työuupumukseen tai sen ennaltaehkäisyyn. Mikä tahansa täydennyskoulutus ei edistä työssä jaksamista, vaan se voi päinvastoin myös uuvuttaa opettajaa. Täydennyskoulutuksen on oltava opettajien näkökulmasta katsottuna laadukasta ja heidän omista tarpeistaan lähtevää. Sitä on myös tarjottava tarpeeksi ajoissa ja säännöllisesti.

Niin opettajien ammatillinen kehittyminen kuin työssä jaksaminenkin nousevat keskeisiksi nyt, kun opettajuudelle asetetut vaatimukset monimutkaistuvat ja muuttuvat jatkuvasti yhteiskunnallisen kehityksen myötä (ks. Luukkainen 2004). Opettajat saattavat kokea jatkuvan kouluttautumisen lisäpaineena tai jopa uhkana. Myös suurten ikäluokkien eläkkeelle jäämisestä seuraava opettajapula edellyttää näihin asioihin paneutumista; on entistä tärkeämpää, että opettajat pysyvät ammatillisesti ajan tasalla ja että he sekä jaksavat että jatkavat opettajan ammatissa. Jos haluamme, että opettajat jaksavat, kehittyvät ja uudistuvat, tulisi heille suoda mahdollisuus myös pysähtymiseen ja oman toiminnan pohtimiseen. Jos jatkuvat vaatimukset uudistumisesta, tehokkuudesta ja erinomaisuudesta unohdettaisiin hetkeksi, voisi opettajille jäädä aikaa ja resursseja myös omasta jaksamisesta ja kehittymisestä huolehtimiseen. Tutkimuksissa ja kehittämishankkeissa on toistuvasti todettu kuinka tärkeää opettajien keskinäinen kollegiaalisuus voi olla opettajien ammatillisen kehittymisen ja henkisen jaksamisen kannalta (Sahlberg 1996; Hargreaves 2003; Stoll, Bolam, McMahon, Wallace \& Thomas 2006).
Toisaalta joissakin kansainvälisissä vertailuissa on opettajien ammatissa jaksaminen jätetty varsin vähälle huomiolle. Esimerkiksi tuoreessa OECD:n raportissa, joka tarkastelee opettajien merkitystä koulutuksen kehittämisessä, ei suoraan puututa työssä jaksamiseen ja uupumiseen (OECD 2005). Raportissa todetaan opettajien jättävän ammattinsa yhä useammin, erityisesti työuran alkuvaiheessa. OECD:n selvityksen mukaan esimerkiksi Yhdysvalloissa joka kymmenes uransa aloittava opettaja vaihtaa alaa kahden ensimmäisen työvuoden aikana. Australiassa joka kolmas selvitykseen osallistunut opettaja suunnitteli uranvaihtoa seuraavan kolmen vuoden kuluessa - heistä vain seitsemän prosenttia aikoi siirtyä eläkkeelle. Sen sijaan etsittäessä syitä työviihtymättömyyteen tai uranvaihtoon, ei ammatillista uupumusta mainita lainkaan. Samoin on asianlaita opettajien ammatillista kehittymistä koskevassa kirjallisuudessa. Esimerkiksi ammatillisten oppimisyhteisöjen (professional learning communities) merkitystä käsittelevässä kirjallisuudessa kosketellaan tätä opettajan työn aluetta varsin marginaalisesti (Stoll ym. 2006). Tämä artikkeli antaa aiheen maltillisuuteen liian kunnianhimoisten ja opettajien työtodellisuuden kannalta liian monimutkaisten kehittämisideoidenkanssa.

Tässä artikkelissa on todettu, että ammatillisen kehityksen ja täydennyskoulutuksen tulisi lähteä opettajien omista tarpeista. Onkin varmasti eri asia, onko täydennyskoulutukseen tai ammatilliseen kehittämiseen osallistuva opettaja valmistunut kaksi tai kaksikymmentä vuotta sitten ja onko hän työssään hyvin jaksava tai kenties täysin loppuunpalanut. Nämä opettajien erilaiset tarpeet, elämäntilanteet ja voimavarat tulisikin ottaa mahdollisimman hyvin huomioon täydennyskoulutuksen suunnittelussa ja toteutuksessa. Tärkeää joka tapauksessa olisi kääntää huomio opettajien jaksamiseen ja jaksamista edistäviin tekijöihin eikä pohtia vain uupumusta ilman ehdotuksia sen voittamiseksi.

Suomalainen opettajien täydennyskoulutusjärjestelmä on ainakin siinä mielessä onnistunut, että opettajat ja koulut voivat viimekädessä päättää millaiseen täydennyskoulutukseen osallistutaan. Pakollinen koulutus on vähentynyt ja virkaehtosopimusten mukaisia kouluttautumisvelvoitteita voi kompensoida joustavasti. Toisaalta koulutukseen kohdistuva tehokkuusajattelu on entisestään tiukentamassa kuntien ja koulujen 
kehittämismäärärahoja. Paikallisen vaikutusvallan lisääminen saattaa olla yksi tärkeä keino hyvien lääkkeiden löytymiseen lisääntyvään ammatilliseen uupumiseen ja samalla oman opettamisen ja koulun kehittämiseen. Mutta se edellyttää rahoitusjärjestelmän luomista jatkuvan ja tarkoituksenmukaisen ammatillisen kehittämisen turvaamiseksi opettajille. Kansainvälisestikin on havaittavissa, että samalla kun opettajien keskinäistä kollegiaalisuutta halutaan lisätä ja päätäntävaltaa siirtää kouluihin, opettajien professionaalisuuden korostaminen on nousemassa uudelleen tärkeäksi. Perushaaste näyttääkin olevan opettajien täydennyskoulutuksen aseman kirkastaminen osana kokonaisvaltaista opettajaksi kasvamista. Tässä elinikäisessä prosessissa täydennyskoulutus sekä sitä oikealla tavalla tukeva omaehtoinen ja kollegiaalinen kehittäminen voivat parhaimmillaan olla opettajalle tervetullut piristys.

\section{Lähteet}

Day, C. (2000). Teachers in the twenty-first century: Time to renew the vision. Teachers and teaching: Theory and practice 6 (1), 101-115.

Easthope, C. \& Easthope, G. (2000). Intensification, extension and complexity of teachers' workload. British Journal of Sociology of Education 21 (1), 43-58.

Fullan, M. (1993). Change forces. Probing the depths of educational reform. London: FalmerPress.

Gabrielsson, U. (toim.) (2001). Opettajuus kriisissä? Tutkijoiden ja kansanedustajien seuran (TUTKAS) julkaisuja, 5/2001.

Hargreaves, A. (1994). Changing teachers, changing times: Teachers' work and culture in the postmodern age. London: Cassell.

Hargreaves, A. (2003). Teaching in the knowledge society. Education in the age of insecurity. New York: Teachers College.

Helakorpi, S., Juuti, P. \& Niemi, H. (1996). Tiimiorganisoitu koulu. WSOY.

Johnson, P. (2006). Rakenteissa kiinni? Perusopetuksen yhtenäistämisprosessi kunnan kouluorganisaation muutoshaasteena. Chydenius-instituutin tutkimuksia 4/2006. Chydenius-instituutti, Kokkolan yliopistokeskus.

Kalimo, R. \& Toppinen, S. (1997). Työuupumus
Suomen työikäisellä väestöllä. Työterveyslaitos.

Kohonen, V. \& Kaikkonen, P. (1998). Uudistuva opettajuus muutosten ja vaatimusten ristipaineessa. Teoksessa H. Niemi (toim.) Opettaja modernin murroksessa. WSOY, 130-143.

Kosunen, T. \& Mikkola, A. (2001). Opettajankoulutuksen tavoitteet ja todellisuus. Kasvatus 32 (5), 478-492.

Kulmala, A. (2000). Opetustyön kuormitustekijät. Työterveyslaitos.

Luukkainen, O. (2000). Opettaja vuonna 2010. Opettajien perus- ja täydennyskoulutuksen ennakointihankkeen (OPEPRO) selvitys 15. Loppuraportti. Opetushallitus.

Luukkainen, O. (2004). Opettajuus: Ajassa elämistä vai suunnan näyttämistä? Acta Universitatis Tamperensis. Tampereen yliopistopaino.

Maslach, C., Schaufeli, W. B. \& Leiter, M. P. (2001). Job burnout. Annual Review of Psychology 52, 397-422.

Meriläinen, M. (1997). Luokanopettajan ammatillinen kehittyminen ja täydennyskoulutus. Teoksessa M.-L. Julkunen (toim.) Opetus, oppiminen, vuorovaikutus. WSOY, 242-270.

Niemi, H. (1989). Mitä on opettajien ammatillinen kehittyminen? Teoksessa S. Ojanen (toim.) Akateeminen opettaja. Täydennyskoulutusjulkaisuja 4/1989. Helsingin yliopisto. Lahden tutkimus- ja koulutuskeskus, 65-99.

Niemi, H., Kivimäki, M., Kuuskoski, E., Lindqvist, M. \& Pursiainen, T. (toim.) (2002). Etiikka koulun arjessa. Otava.

OECD (2005). Teachers matter. Attracting, developing and retaining effective teachers. Paris: OECD.

Opettajankoulutuksen kehittämisohjelma. (2001). Opetusministeriö. Koulutus- ja tiedepolitiikan osasto.

Sahlberg, P. (1996). Kuka auttaisi opettajaa. Postmoderni näkökulma opetuksen muutokseen yhden kehittämisprojektin valossa. Jyväskylän yliopisto: Jyväskylä Studies in Education, Psychology and Social Research, 119.

Sahlberg, P. (1997). Opettajana koulun muutoksessa. Opetus 2000 -sarja. WSOY. 
Simola, H. (1998). Toiveet, lupaukset ja koulun arki-opettaja muutoksen puristuksessa. Teoksessa O. Luukkainen (toim.) Tulevaisuuden tekijät. Uuden opettajuuden mahdollisuudet. Atena Kustannus.

Stoll, L., Fink, D. \& Earl, L. (2003). It's about learning (and it's about time). London: RoutledgeFalmer.

Stoll, L., Bolam, R., McMahon, A., Wallace, M. \& Thomas, S. (2006). Professional learning communities: A review of the literature. Journal of Educational Change, 7 (4), 221-258.

Syrjäläinen, E. (2002). Eikö opettaja saisi jo opettaa? Koulun kehittämisen paradoksi ja opettajan työuupumus. Tampereen yliopiston opettajankoulutuslaitoksen julkaisuja A 25/2002.

Talib, M.-T. (1999). Toiseuden kohtaaminen kouIussa. Opettajien uskomuksia maahanmuuttajaoppilaista. Tutkimuksia 207. Helsingin yliopiston opettajankoulutuslaitos.
Tuominen, H. (2002). Jaksaako opettaja kehittyä? Ammatillisen kehityksen ja täydennyskoulutuksen merkitys opettajien työssä jaksamisessa. Helsingin yliopisto. Kasvatustieteellinen tiedekunta. Kasvatustieteen laitos. Pro gradu -tutkielma. http://ethesis.helsinki.fi/julkaisut/kas/kasva/pg/tuominen/

Vartiovaara, I. (1996). Burnoutista jaksamiseen - aika itkeä, aika iloita. Otava

Viinamäki, T. (1997). Opettajien ja sosiaalityöntekijöiden psyykkinen rasittuneisuus. Väitöskirja. Kuopion yliopiston julkaisuja E. Yhteiskuntatieteet 50. Kuopion yliopisto.

Wilhelm, K., Dewhurst-Savellis, J. \& Parker, G. (2000). Teacher stress? An analysis of why teachers leave and why they stay. Teachers and teaching: Theory and practice, 6 (3), 291-304.

Artikkeli saapui toimitukseen 4.10.2006.

Se hyväksyttiin julkaistavaksi toimituskunnan kokouksessa 15.1.2007. 